\title{
Teaching Certificates Earned Online and Hiring Practices of High School Principals
}

\author{
Jonathan Adams (Corresponding author) \\ College of Communication and Information \\ Florida State University, Gainesville, FL 32611, United States \\ E-mail: jladams@fsu.edu
}

Received: August 27, 2015 Accepted: September 30, 2015

Published: February 17, 2016

doi:10.5296/jei.v2i1. $8203 \quad$ URL: http://dx.doi.org/10.5296/jei.v2i1.8203

\begin{abstract}
A national survey of United States high school principals $(\mathrm{n}=2,187)$ was used to assess the acceptability of job applicant qualifications that included degrees earned either online, partly online, or in a residential teacher-training program. The applicants with coursework taken in a residential setting were overwhelmingly preferred over applicants holding a degree earned partly or wholly online. Analysis indicated that the type of institution, personal experience and perceived benefits of face-to-face interaction play an important role in the formation of the perceived quality of online degree, programs and courses.
\end{abstract}

Keywords: Distance education, Acceptability, Hiring, Teacher certification, High school, Principals

\section{Introduction}

The widespread availability of online university courses have benefited millions of Americans seeking to earn a degree, maintain a professional certificate or earn a few extra college credits. For example, distance education has provided new educational opportunities for military personnel, professionals working in rural areas and single parents who not able to attend classes on campus. While such programs have benefited millions of people, it has been noted that questions about quality have a negative effect on the ability of recent graduates to compete for employment (Adams, 2008).

In recent times, the unemployment rate has made it easier for graduates in certain disciplines, but with higher education programs producing more than twice the number of teachers that are actually needed jobs in secondary schools (Greenberg et al., 2015), employers can more 
selective. While the unemployment rate has declined significantly in recent times, the employment outlook for high school teachers is expected to be slower than the average over the next ten years (Bureau of Labor Statistics, 2015). This suggests that employment prospects for recent graduates in secondary education will be hinge on strong recommendations, personal attributes, academic specialization and the reputation of the degree-granting institution as the factors that define the quality of their application.

The current research investigates whether distance learning and traditional degrees hold equal weight in hiring decisions for entry-level teaching positions. A national survey of high school principals was conducted to evaluate whether online degrees are perceived to have the same prestige as those earned by attending classes on campus. The purpose is to understand the perceived, marketplace value attached to college degrees earned online and the factors that influence the acceptability of such degrees in hiring situations specific to the teaching profession. The current research is not directly concerned with why students chose to enroll, whether educational outcomes are equivalent or with the merits of distance learning.

\subsection{No Significant Difference}

There are hundreds of studies that have sought to evaluate the educational accomplishments of distance education students as compared with students enrolled in residential courses. A majority of such research studies report that student outcomes such as achievement, retention or student satisfaction are all equal to - or exceed - traditional residential class work. These so-called media comparison studies date back to the early $20^{\text {th }}$ century. Media comparison studies have continued to be popular in recent times as a method to evaluate computer-based distance learning. For example, such methods are employed to evaluate computer-based instruction as compared with residential class work (Taylor, 2001). Distance education supporters frequently point to the sheer number of no significant difference phenomenon (Russell, 1999) media comparison studies as proof that learning at a distance is as effective as instruction delivered in a classroom.

Media comparison research often compares student outcomes of a college course that is offered online or face-to-face. The student-participants enroll in the version of the course (online or face-to-face) that they prefer. The research methods seldom require students to be randomly assigned to one group or another. Research designed in this manner assumes that it is only whether students are taking their class online or in a face-to-face environment that makes a difference in academic performance. Teaching strategies, student learning styles or selection bias are seldom mentioned as having an influence on the grades or satisfaction scores which are used as points of comparison. Because of these flaws, some scholars have suggested that no significant difference phenomenon findings are misleading and their conclusions have done little more than raise more questions than they answer (Phipps \& Merisotis, 1999).

While the media comparison research methods used to evaluate the quality of distance education classes are questionable, distance institutions also appear to be their own worse enemy when it comes to public relations. National news stories about false advertising (Carnevale, 2002), aggressive enrollment tactics (Hebel, 2006), fraudulent marketing 
practices (Government Accounting Office, 2010), and the availability of fake degrees (Varselona, 2006; Bartlett \& Smallwood, 2004) have served to support an unwarranted association between accredited institutions and those that are not (Blumenstyk, 2005). It may be difficult for people to distinguish between legitimate, high quality distance education programs and unaccredited institutions when such problems arise (Greenberg et al., 2015). Consequently, negative news tends to have some impact on the credibility of all distance education institutions, programs and courses.

A broader review of distance education research suggests that distance education instructional methods and learning outcomes have consistently improved (Allen \& Seaman, 2009). For instance, benchmarks that have been developed to track the administration, design, and delivery of online instruction appear to have resulted in improved teaching models and pedagogical practices for distance teaching (Bernard et al., 2004). In recent times, a number of online institutions have been recognized for exceptional teacher education programs. For example, the National Council for Accreditation of Teacher Education (NCATE) has accredited many teacher certification programs that are taught entirely online as offered by public and private colleges and universities. The National Council for Teacher Quality lists two such programs - Dallas Baptist University and Western Governors University - among the top teacher training programs in the country, praising these schools with tremendous "commitment and focus" in their efforts to provide the training that teachers need to be prepared to enter the classroom (Greenberg et al., 2015, p. 12).

\subsection{The Principal as a Hiring Manager}

Some researchers have argued that too much attention has been paid to the supply-side aspect of the teaching profession, and, therefore, the important role that the principal plays has been overlooked (Harris et al., 2010). It is important to note that principals are involved in every aspect of the administration of a school. For example, principals oversee facilities management, administer finances, assure the welfare of the students, manage public relations and mentor teachers (Trail, 2000). While human resource management is among a principal's more important administrative responsibilities, no decision is more important than attracting and hiring the best teachers (Bolz, 2009; Peterson, 2002).

Interestingly, in hiring situations principals tend to value an applicant's personal qualities more so than professional characteristics. In a comprehensive study of school administrator hiring practices, Harris et al. (2010) developed a list of characteristics that principals most often prefer to find in teacher applicants. They found that principals ranked strong communication skills, enthusiasm and classroom management skills highest. In a different study, Mason and Schroeder (2010) noted that professional characteristics such as proper certification, letters of reference, and transcripts are important and that principals use interviews to gauge personal attributes. Principals, then, tend to deem interviews, references, evaluations, and letters of recommendation as more effective means of learning about their applicants than coursework or strong academic credentials. 


\subsection{The Acceptability of Online Degrees}

Lewin (1941, p. 37) was the first to explore "gatekeeper" attitudes and behavior by focusing on the factors that influence the acceptability of food products and the determinants of their value. While Mitchell (2003, p. 1) has noted has noted that a hiring process may be influenced by a number of gatekeepers (i.e. receptionists, recruiters, and resume screeners), the current research describes a gatekeeper as "the person who makes the final decision in hiring situations." It has been suggested that a hiring gatekeeper's perception of hirability can be understood by assessing the value they assign to certain traits and their preferred methods of assessing job candidates. For example, principals who prefer to weigh personal attributes as having the most value will rate job applicants who are perceived to be conscientious better than others (Topor et al., 2007).

A number of research studies have been conducted to evaluate how hiring managers perceive the value of online degrees in business professions. For example, hiring managers that supervise pharmaceutical labs were found to be reluctant to accept such credentials. The managers were skeptical about the reputation of the institution and the rigor of online degrees because they believed online courses limit the exchange of ideas between students and the professor (Chaney, 2002). Other research has shown a strong preference for applicants with a residential degree as compared to applicants with an online degree or a degree earned partially online (Adams \& DeFleur, 2006; Adams et al., 2007).

Research that has examined the acceptability of online degrees in schools colleges and universities also suggests that job applicants who earn a degree online (or partially online) are not judged as having qualifications that are equal to those of graduates who earn their degrees in a residential setting. For instance, academicians in technical colleges have expressed reservations about hiring new faculty who have earned their doctoral degree online (Flowers \& Baltzer, 2006) as have deans and departmental chairs in research institutions (Adams \& DeFleur, 2005). Several studies have noted a similar phenomenon in public schools. A survey of elementary, middle and high schools found principals to be apprehensive about hiring prospective teachers who had earned their degree online. The principals noted "compromised social aspects" as a source of concern (Huss, 2007). Finally, a research study that compared the perceived value of online and residential degree programs in health, business and academia found that hiring managers expressed reservations about online degree programs because of limited face-to-face interaction between students and teaching faculty (Adams, 2008).

The current research, then, investigates whether distance learning and traditional degrees hold equal weight in hiring decisions for entry-level teaching positions. The current research is not directly concerned with why students chose to enroll, whether educational outcomes are equivalent or with the merits of distance learning. Comments written by the principals on the surveys were also analyzed in order to explore meaningful connections between applicant choices and their perceptions of value. The current study, then, is concerned only with evaluating the mode of education as a criterion for employment. The purpose of the current research is to understand the perceived, marketplace value attached to college degrees earned 
online and the factors that influence the acceptability of such degrees in hiring situations specific to the teaching profession.

\section{Method}

Contact information for principals was obtained through a government Web site listing of all schools by district in each state. While finding the Web site information was not difficult, each state formatted the contact information for public, private and alternative schools differently. The contact lists for each state were quite extensive. Considerable effort was made to create a standardized format and to separate those states which provided email contact information from those which provide only a physical address.

In order to simplify the task of standardizing contact lists, inclusion requirements were used. Each state contact list had to list the name of the principal and either an email or physical address for every high school. Forty-five states were found to have a high school contact list but only thirty-eight states met these inclusion criteria. As a result of this process, two contact lists were generated; one for electronic surveys and one for paper surveys that were delivered by surface mail. The researchers contacted some principals by email and directed them to Qualtrics (an online survey tool) and also mailed a large number of paper surveys for those states that did not list an email address for their high schools.

While the researchers preferred to make contact electronically, it was soon discovered that email was very unreliable. For instance, many email transmissions "bounced" because the email addresses were bad or they were rejected by anti-spam software. Qualtrics allowed the researchers to determine that 1,852 potential respondents interacted with the survey. Specifically, there were 713 respondents, 341 viewed the survey without participating, 700 clicked-through the survey (without viewing) and 98 principals requested to be unsubscribed from the contact list without viewing or clicking-through.

A considerable number paper surveys were delivered $(n=4,678)$ by surface mail. A questionnaire was sent to each principal, accompanied with a letter of introduction and a postage-paid return envelope. Due to problems with processing such a large number of questionnaires, only one follow-up mailing was made to non-respondents. Questionnaires sent by surface mail resulted in 67 bad addresses and three that were damaged resulting in 70 discarded questionnaires. In total, 1,474 questionnaires were collected for a $32 \%$ return. When combined with the questionnaires collected from the web-based survey, the survey resulted in 2,187 completed questionnaires.

The questionnaire was divided into four parts. In the first section, the qualifications of three applicants were described as being the same except for the manner in which their degree was earned. The principals were then asked to select the most qualified applicant in two hiring situations. In the second section, the participants were presented with the opportunity to clarify their applicant choices by responding to questions and providing written comments. Background information was collected in the third section and the final section provided a blank page for additional comments.

Three teaching position applicants were introduced as having the similar positive qualities. 
Specifically, each of the applicants was described as having similar academic credentials, successful student teaching experiences, good letters of recommendation, positive results from personal interviews and a teaching certificate recognized by a state board of education. Thus, the applicants' qualifications were identical except for the academic environment in which their degrees were earned. Two hiring situations followed, with instructions for respondents to pick the more desirable applicant in each situation (Table 1).

Table 1. Description of the applicants in two hiring situations included in the questionnaire

\begin{tabular}{|l|}
\hline Hiring Situation 1: \\
\hline Applicant A, described as a graduate of a traditional-residential degree program \\
Applicant B, described as a graduate of an online degree program. \\
\hline Hiring Situation 2: \\
\hline $\begin{array}{l}\text { Applicant A, described as a graduate of a traditional-residential degree program } \\
\text { Applicant C, described as a graduate of a degree program that included an equal mix of online and } \\
\text { traditional-residential classroom studies. }\end{array}$ \\
\hline
\end{tabular}

\subsection{Quantitative Results}

While responses came from 38 states, participants from 15 states accounted for $88 \%$ (n $=$ $1,914)$ of the surveys collected. Eight of the 13 states whose principals were contacted by surface mail contributed $69 \%(\mathrm{n}=1,504)$ of the survey responses. The high school data was categorized by metropolitan district with $43 \%$ of the schools categorized as rural $(n=927)$, $36 \%(\mathrm{n}=752)$ suburban and 21\% $(\mathrm{n}=452)$ urban. Median enrollment was 500 students for urban schools $(n=442), 1,107$ students for suburban schools $(n=763)$, and $426(n=926)$ for schools located in rural areas.

Women represented $26 \%(\mathrm{n}=559)$ of the respondents. While a majority of the respondents were older than $45(n=1,525)$, most $(63 \%)$ had worked fewer than 10 years as a high school principal and only $9 \%(n=200)$ had worked more than 21 years in administration. While a number of the respondents were employed by alternative, charter and church affiliated schools, the majority were employed by public $(79 \% ; \mathrm{n}=1,736)$ and $(16 \% ; \mathrm{n}=350)$ private schools. The number of high schools that have offered distance classes $(n=1,485)$ or plan to offer distance classes in the future $(\mathrm{n}=1,657)$ are comparable to national averages by metropolitan district as previously reported by Zandberg and Lewis (2008).

In the first hiring situation the alternate applicant (applicant B) was described as having earned a teaching certificate course work completely online. In this hiring situation, 2,039 of the respondents selected a job applicant, with $96 \%(\mathrm{n}=2,117)$ indicating that they would recommend hiring the applicant with a traditional-residential degree. Only $4 \%(n=78)$ of the 


\section{Macrothink

respondents were likely to recommend the applicant with all of their course work completed online as the most qualified the applicant.

In the second hiring situation, the alternate applicant (applicant C) was described as having earned a teaching certificate by completing one-half of their course work online. In this situation, 2,081 respondents selected one of the two applicants, with 73\% $(\mathrm{n}=1,518)$ selecting the job applicant with a traditional-residential degree and $27 \%(\mathrm{n}=563)$ of the respondents indicated that they would accept the applicant who had completed one-half of the course work online.

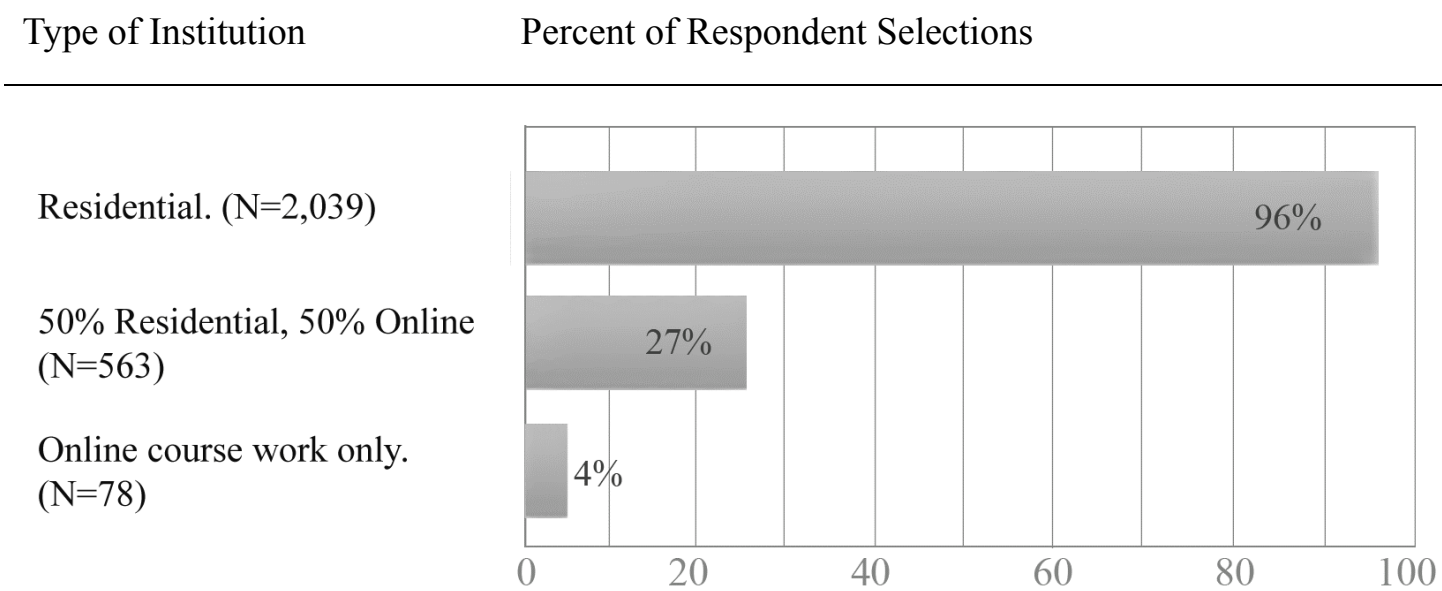

Figure 1. Percentage of respondents who responded to candidate selection

Note. Distribution of responses to "Yes, I would be likely to recommend this person as the most qualified applicant for a teaching position."

In the second section of the questionnaire, the administrators were asked to clarify why they made their choices in the hiring situations. Several questions were posed with checkbox options to agree, disagree, or indicate their indecision on the relevance of online courses in their institution. Following each of these questions, a space was left blank with an invitation for respondents to write-in comments that could clarify their checkbox selections.

When asked if the type of educational institution (online university or residential university) from which the applicant obtained his or her degree would be of no importance in a hiring situation, $77 \%(\mathrm{n}=1,657)$ of the principals disagreed. While $49 \%(\mathrm{n}=1,050)$ of the principals indicated that they thought a successful student teaching experience and good recommendations are more important in hiring decisions, $51 \%(n=1,150)$ indicated that core classes cannot be taught effectively online (see Table 2 ). 
Table 2. Summary of responses to qualifying statements

\begin{tabular}{|l|l|l|l|l|}
\hline Statement & Agree & Disagree & Undecided & $\mathrm{N}$ \\
\hline $\begin{array}{l}\text { 1. The type of educational institution (online } \\
\text { university, residential university) from which } \\
\text { the applicant obtained his or her degree would } \\
\text { be of no importance. }\end{array}$ & $13 \%$ & $77 \%$ & $10 \%$ & 2,165 \\
\hline $\begin{array}{l}\text { 2. Core teacher education classes (i.e. methods, } \\
\text { curriculum, and educational philosophy) can be } \\
\text { effectively taught over the Internet to students } \\
\text { enrolled in online courses. }\end{array}$ & $31 \%$ & $51 \%$ & $18 \%$ & 2,174 \\
\hline $\begin{array}{l}\text { 3. It is not important how many credits are } \\
\text { earned over the Internet in online courses, a } \\
\text { successful student teaching experience and } \\
\text { good recommendations are more important in } \\
\text { our hiring decisions. }\end{array}$ & $49 \%$ & $35 \%$ & $16 \%$ & 2,166 \\
\hline
\end{tabular}

Note. Question 1 percentages are based on $\mathrm{N}=2,165$ (4 non-respondents); Question 2 percentages are based on $\mathrm{N}=2,174$ (7 non-respondents); Question 3 percentages are based on $\mathrm{N}=2,166$ (13 non-respondents).

A correlation analysis was conducted to learn if any relationship exists between various characteristics and job applicant selections in the two hiring scenarios. Because it has been suggested that familiarity (or experience) with distance education might affect unfavorable employer attitudes, previous experience (enrolling in or administrating) online courses was singled out for analysis in conjunction with applicant selection (in the hiring situations).

Table 3 shows that the principals who had previously taken an online class were more likely to choose the alternative applicant (B or $\mathrm{C}$ ). While the number of principals that selected applicant B (online courses only) is relatively small, the results are significant. Clearly, principals who have never taken an online class are far more likely to select applicant A, the applicant who earned all of their college credits in a residential program. The results are perhaps more important for the alternative applicant $\mathrm{C}$ (an equal mix of online and residential courses), where the number of times that applicant was acceptable by principals with no experience with online courses. 


\section{Macrothink}

Table 3. Chi Square analysis of candidate selection by hiring situation and whether the respondent has taken online courses previously

\begin{tabular}{|l|l|l|l|}
\hline & \multicolumn{2}{l|l|}{ Took online classes for credit } \\
\hline & Yes & No & \multicolumn{1}{l|}{ Total } \\
\hline Hiring Situation 1: Likely to Recommend * & & & \\
\hline $\begin{array}{l}\text { Applicant A: Degree completed with all } \\
\text { traditional-residential coursework }\end{array}$ & $94.5 \%$ & $98.1 \%$ & $96.3 \%$ \\
\hline $\begin{array}{l}\text { Applicant B: Degree completed with all online } \\
\text { coursework }\end{array}$ & $5.5 \%$ & $1.9 \%$ & $3.7 \%$ \\
\hline $\begin{array}{l}\text { Hiring Situation 2: Likely to Recommend } * \\
\text { Applicant A: Degree completed with all } \\
\text { traditional-residential coursework }\end{array}$ & $64.4 \%$ & $81.4 \%$ & $72.9 \%$ \\
\hline $\begin{array}{l}\text { Applicant C: Degree completed with 50\% online } \\
\text { and 50\% residential coursework }\end{array}$ & $35.6 \%$ & $18.6 \%$ & $27.1 \%$ \\
\hline & $* n=2,070, X^{2}=75.183, d f=1, p \leq .001 * * *$ \\
\hline
\end{tabular}

Note. Category totals differ from raw totals because several respondents did not indicate their choice or did not select an applicant.

A correlation analysis was conducted to test whether a relationship exists between applicant selection and administrative experience with online courses. Interestingly, there appears to be no relationship between these two factors in situation one (Table 4). However, the findings were significant for the alternative applicant $C$ (situation two). In other words, principals that work in schools which offer online courses are significantly more likely to hire applicants with a mix of online and traditional-residential coursework. 
Table 4. Chi Square analysis of candidate selection by hiring situation and whether the school in which the respondent works has offered online classes for credit in the past

\begin{tabular}{|l|l|l|l|}
\hline & \multicolumn{2}{|l|}{ Has offered online classes for credit } \\
\hline & Yes & No & Total \\
\hline Hiring Situation 1: Likely to Recommend * & & & \\
\hline $\begin{array}{l}\text { Applicant A: Degree completed with all } \\
\text { traditional-residential coursework }\end{array}$ & $95.8 \%$ & $97.4 \%$ & $96.3 \%$ \\
\hline $\begin{array}{l}\text { Applicant B: Degree completed with all online } \\
\text { coursework }\end{array}$ & $4.2 \%$ & $2.6 \%$ & $3.7 \%$ \\
\hline $\begin{array}{l}\text { Hiring Situation 2: Likely to Recommend * } \\
\text { Applicant A: Degree completed with all } \\
\text { traditional-residential coursework }\end{array}$ & $70.3 \%$ & $* n=2,109, X^{2}=3.545, d f=1, p \leq .06$ \\
\hline $\begin{array}{l}\text { Applicant C: Degree completed with 50\% online } \\
\text { and 50\% residential coursework }\end{array}$ & $29.7 \%$ & $21.8 \%$ & $27.1 \%$ \\
\hline & & & \\
\hline
\end{tabular}

Note. Category totals differ from raw totals because several respondents did not indicate their choice or did not select an applicant.

In summary, a correlation analysis between various factors revealed that previous experience taking an online course or having administrative experience in a school that offers online courses appear to be predictors of how a principal may select a job applicant. However, these results seem to be the strongest for candidates who have a mix of online and residential classes. Because these associations appear to influence the applicant selection behavior of hiring managers, a content analysis was conducted to learn more about why these relationships appear to effect applicant selection outcomes.

\subsection{Qualitative Results}

The principals were offered the opportunity to write down responses to questions asked in the second and last part of the questionnaire. The written comments were analyzed using a constant comparative method (Glaser \& Strauss, 1967). For instance, statements were 
assigned to categories as they emerged from the data and were refined as the analysis continued. The purpose of this analysis was to define the perceptions that influenced applicant selections and to determine the most likely sources of information that influenced those perceptions.

Of the 2,187 respondents, $58 \%(\mathrm{n}=1,262)$ provided written comments at various points in the questionnaire. The comments were transcribed using word processing software. This data totaled 69,872 words; about 260 pages using New Time Roman in single space format. Catpac, a computer software tool designed to facilitate qualitative analyses, was used to identify keyword frequencies and clusters of related keywords that appear in the text. The keyword frequencies help to identify categories and clusters that are present. Keyword clusters were organized using a constant comparative method to develop and interpret recurring thematic categories (Gay, 1992), which are supported by specific examples drawn from the comments.

The quantitative analysis revealed that principals prefer to hire applicants with degrees earned in a residential setting. Prior experience with online courses appears to be related to the development of attitudes toward online degrees (and courses) in hiring situations, particularly where applicants have an equal mix of coursework. Personal experience is only one aspect of how attitudes are developed however, and the qualitative analysis provided some insight into the channels of communication that principals drew upon to inform their impressions about online learning. The survey asked the principals to name the sources of information (e.g. news, friends, and colleagues) that they considered most important, or which sources had the greatest influence on their opinion about distance education.

Nearly $41 \%$ of the $(n=893)$ principals answered this a question, with many providing several sources of information they relied upon to make their judgements. Because some respondents listed several sources while others wrote only one, a total of 1,474 items were recorded, compiled, sorted and arranged by frequency (Table 5). It is noteworthy that the principals most often responded that their perceptions were formed through their own personal experiences or by the personal experiences with online courses by a colleague, staff member or family member. The principals appear to recognize the importance of news and research but appear to rely less on these sources than their own personal experience and the personal experiences of close associates. Interestingly, the reputation of the institution where the teaching certificate was earned was mentioned more often than friends and family. 


\section{Macrothink}

Table 5. Channels of information used to form opinions of the acceptability of distance education classes

\begin{tabular}{|c|c|c|}
\hline Category of response & $\mathrm{N}$ & Example of written response \\
\hline Personal experience & 878 & $\begin{array}{l}\text { "Personal experience with teachers with various backgrounds in } \\
\text { teacher population." } \\
\text { "Observation of teachers and student teachers who have done } \\
\text { such courses." }\end{array}$ \\
\hline Colleagues & 212 & $\begin{array}{l}\text { "Our staff -- many are beginning distance education classes. } \\
\text { Some have been positive with good follow-up, some negative } \\
\text { with little interaction." } \\
\text { "Feedback from trusted staff members -- his or her personal } \\
\text { experiences with online courses." }\end{array}$ \\
\hline $\begin{array}{l}\text { Reputation of the } \\
\text { institution }\end{array}$ & 186 & $\begin{array}{l}\text { "The credibility of the institution where the degree of credit is } \\
\text { earned would determine acceptability." } \\
\text { "Credibility, reputation of the university providing courses." }\end{array}$ \\
\hline Friends and family & 131 & $\begin{array}{l}\text { "My wife took online courses to attain masters and + } 60 \text { status." } \\
\text { "My son took two undergraduate courses online." }\end{array}$ \\
\hline News & 119 & "News." \\
\hline Research & 115 & $\begin{array}{l}\text { "Professional research conducted on the program." } \\
\text { "Personal experience or research backed evaluation." }\end{array}$ \\
\hline
\end{tabular}

In the second section of the survey, two questions generated more comments than others. The first asked whether the type of educational institution (online university, residential university) from which the applicant obtained his or her degree would be of no importance. A vast majority of the comments to this question expressed a concern that the role distance education plays in teacher training. For example, the respondents most frequently expressed concern for the perceived quality of online courses. The overall tone of the comments expressed doubt as to whether courses that do not include face-to-face contact with professors, fellow students and mentors are appropriate for a profession that relies so heavily on social skills. In this context, respondents used keywords such as experience, face-to-face learning and interaction to describe the important differences between online and residential coursework. One respondent summarizes the predominant tone of this category as follows: 
"From my experience, I have observed that most of the students who take on-line courses do so because they feel it is easier academically. They often find that the tuition fees are less and time frame is shorter. I strongly feel that students who take on-line courses are missing out in classroom dialogue and interaction with other students and professor, even though students are able to communicate among each other electronically. These "graduates" are going to teach our students in a traditional classroom?"

"A college degree is about more than just completing course work. I like to see involvement in the college experience - the contributions the graduate has made, not just the grades they have earned. The interaction with the faculty and staff on campus is invaluable. A teacher has to interact with people, not a computer."

"I've had both types of courses and found the internet course to be of lesser quality. The schooling profession is all about people and relationships. People who are physically present and in need of our personal face to face communication. I think the traditional setting is better preparation for what we do every day."

The second question that generated many comments asked the principals whether they thought "core" teacher education classes (i.e. methods, curriculum, and educational philosophy) are effective if taught over the Internet to students enrolled in online courses. The concerns expressed to this question were focused on teaching methods or practice-oriented courses where teachers learn about and practice teaching techniques. Such courses rely on mentor relationships, peer interaction, and reflective discussions to prepare pre-service teachers for field experiences. While roughly half of the respondents indicated that some courses in a teacher education curriculum might be acceptable if taken in an online setting, methods courses could not - and should not - be taught online. The theme of such comments centered on the importance of personal relationships.

"I don't believe methods courses can be effectively taught online. The human component of teaching must be emphasized in teaching methodologies. Relationships are so important to instruction, and I don't believe that an online course can match an effective classroom teacher's modeling."

"Too much of what you know or need to pick up you can only get from a live teacher, in a live classroom, with live peers. Experience and sharing are too valuable to give up. Reading and analyzing questions by yourself on a computer is a lonely, less meaningful way to learn. Thus, making it less likely to remember or put to use. There are little or no absolutes in teaching and administration, they making the only way learned of studies out of date, out of place or just a small piece of the puzzle. Whereas the approaches, views, experiences shared and exposed in the traditional class could make you a more well rounded, marketable and give you staying power which should be high on your list."

Finally, the questionnaire presented an opportunity for the principals to provide closing remarks or opinions. The closing comments were more extensive and appeared to represent a more balanced view of online learning. While most of the comments reiterated strong sentiments about the importance of face-to-face communication, the development of social 
skills and mentored relationships, there were some positive themes that emerged, particularly with regards to experience with technology. Within this subgroup of comments, a mix of residential and online coursework was thought to be advantageous for the candidate and for their students.

"I believe that a teaching candidate needs to have a broad base experience. I believe that most teaching candidates would need to have a good mixture of classroom taught courses as well as online learning experiences. The future of education is moving toward more online learning and a candidate who has that type of experience would be valuable to a school building's learning environment."

\section{Discussion}

The results of the current study indicate that recently graduated teachers from online certification programs are less likely to find gainful employment in desirable school districts that attract many applicants. The results suggest that high school principals will likely pass over those applicants who have earned their teaching credentials online in favor of those applicants who have earned their credentials from traditional-residential programs. The results imply that online teacher training may result in discouraging employment prospects especially for recent graduates who have limited professional teaching experience. Teacher education programs are turning out certified teachers at a rate that exceeds market demand, and for teachers who have limited teaching experience online teaching-training programs do not appear to give applicants an "edge" over their peers who attend teacher training programs in a residential setting.

It is interesting to note that two online teacher training programs have been recognized for excellence but the responses to the current study indicate that the overall quality of online programs is viewed as unfavorable. The institutions that are recognized for their excellence have not yet won the respect that they deserve from high school principals in hiring situations. Among those principals who are willing to accept some classes taken online, the respondents mentioned that the core knowledge such as methods, classroom management and the student teaching practicum should be taught in a face-to-face setting. The respondents questioned how the important concepts from the core classes might be taught virtually, and how practicum supervision might be arranged.

While online courses were regarded as unacceptable for teacher training, many principals mentioned in their comments that online course credit hours were accepted for professional development. This seems to indicate that there is some acceptance of online learning, at least in the case of online courses taken to support a teaching credential.

The introduction of online teacher-education programs has interesting new implications for teacher preparedness research, retention and how online programs compare to other alternative certification pathways. Authorizing such programs may offer certain benefits perhaps a greater interest in teaching and a subsequent expansion in the number of certified teachers - but there are no assurances that online teacher certification programs actually benefit the teachers who are new to the profession. Specifically, whether online coursework 
improves the development of psycho-social factors such as attitudes, values, moral development and mastery remain important yet unanswered questions. Clearly, in the hiring situations presented in the current research, acceptability is tied to the perception that online coursework does not offer pre-service teachers the same opportunities to learn the social and cultural aspects of the profession. At the same time, the results also appear to suggest that teaching experience, recommendations and the school system where applicants have taught previously trump the questions regarding the manner in which a teaching certificate was earned.

Finding solutions to the challenges uncovered in the current research will not be easy. For-profit institutions have a great deal of influence and will likely press ahead with plans to expand and improve their capabilities to offer high quality teacher certification programs. While all universities are under pressure to balance quality and growth, the goal of online teacher education programs appears to be moving toward replicating traditional programs. Again, while there are online programs that have been recognized for excellence, the results of the current study imply that such programs have yet to improve the viability of prospective teachers in the job market.

While the popularity of distance education is compelling, this mode of learning should be used with careful consideration. Current research suggests that online teacher training has the potential to compete with traditional-residential programs, offer professional development for practicing teachers, and improve specific problems related to teacher training, student retention, and job satisfaction in the profession. However, the findings of the current study are clear; a degree earned entirely or partially online is not equivalent for the purposes that they are intended to serve as compared to a degree earned in a residential setting.

\section{References}

Adams, J. (2008). Understanding the factors that limit the acceptability of online courses and degrees. International Journal on E-Learning, 7(4), 573-587.

Adams, J., \& DeFleur, M. (2006). The acceptability of online degrees as a credential for obtaining professional employment. Communication Education, 55, 1. http://dx.doi.org/10.1080/03634520500343376

Adams, J., \& DeFleur, M. (2005). The acceptability of a doctoral degree earned online as a credential for obtaining a faculty position. American Journal of Distance Education, 19(2), 71-85. http://dx.doi.org/10.1207/s15389286ajde1902_2

Adams, L., DeFleur, M., \& Heald, G. (2007). The acceptability of online degrees in the health professions. Communication Education, 56, 3. http://dx.doi.org/10.1080/03634520701344959

Allen, I., \& Seaman, J. (2009). Learning on Demand: Online Education in the United States, 2009. Retrieved from http://www.sloan-c.org

Bartlett, T., \& Smallwood, S. (June 25, 2004). Let me be honest with you. The Chronicle of Higher Education, 50, A15. 
Bernard, R. M., Abrami, P. C., Lou, Y., Borokhovski, E., Wade, A., Wozney, L., \& Fiset, M. (2004). How does distance education compare with classroom instruction? A meta-analysis of the empirical literature. Review of Educational Research, 74(3), 379-439. http://dx.doi.org/10.3102/00346543074003379

Blumenstyk, G. (January 31, 2005). For-profit education companies brace themselves for ' 60 Minutes' expose. Chronicle of Higher Education, 51, A28.

Bolz, A. J. (2009). Screen teacher candidates: Luck of the draw or objective selection. Dissertation Abstracts, University of Wisconsin, Madison, USA.

Bureau of Labor Statistics. (2015). U.S. Department of Labor, Occupational Outlook Handbook (2014-15 ed.). High School Teachers, on the Internet. Retrieved from http://www.bls.gov/ooh/education-training-and-library/high-school-teachers.htm

Carnevale, D. (September 6, 2002). Colleges demand that fakedegrees.com remove their names from its web site. Chronicle of Higher Education, 49, A44.

Carnevale, D., \& Olsen, F. (June 13, 2003). How to succeed in distance education. The Chronicle of Higher Education, 49(40), A31.

Chaney, E. G. (2002). Pharmaceutical employers' perceptions of employees or applicants with e-degrees or online coursework. Ph.D. dissertation, Indiana State University, Indiana, United States. ABI/INFORM Global (Publication No. AAT 3061561).

Field, K. (July 11, 2010). Government vastly undercounts defaults. The Chronicle of Higher Education. Government. Retrieved from http://chronicle.com/article/Many-More-Students-A $\mathrm{re} / 66223$

Flowers, J. C., \& Baltzer, H. (2006). Hiring Technical Education faculty: Vacancies, criteria, and attitudes toward online doctoral degrees. Journal of Industrial Teacher Education, 43(3), $29-44$.

Gay, L. (1992). Educational research: Competencies for analysis and application. Ontario, Canada: Macmillan.

Greenberg, J., Walsh, K., \& McKee, A. (2015). NCTQ Teacher Prep Review 2014: Review of the nations' teacher preparation programs. National Council on Teacher Quality. $1120 \mathrm{G}$ Street, NW, Suite 800, Washington, DC. Retrieved from http://www.nctq.org/teacherPrep

Glaser, B., \& Strauss, A. (1967). The discovery of grounded theory: Strategies for qualitative research. Chicago: Aldine Publishing Company.

Government Accounting Office. (2010). For-profit colleges: Undercover Testing Finds Colleges Encouraged Fraud and Engaged in Deceptive and Questionable Marketing Practices. Highlights of GAO-10-948T, a testimony before the Committee on Health, Education, Labor, and Pensions, U.S. Senate. U.S. Government Accounting Office. Retrieved from http://www.gao.gov

Harris, D. N., Rutledge, S. A., Ingle, W. K., \& Thompson, C. C. (2010). Mix and Match: 
What Principals Really Look for When Hiring Teachers. Education Finance and Policy, 5(2), 228-246. http://dx.doi.org/10.1162/edfp.2010.5.2.5205

Hebel, S. (January 23, 2006). New York Regents place moratorium on approving new for-profit colleges or programs. The Chronicle of Higher Education. Retrieved from http://chronicle.com/daily/2006/01/2006012304n.htm

Huss, J. (2007). A Tri-State Study: Administrator Attitudes Toward Online Teacher Preparation Programs: Are Principals Logging On-or Logging Off? International Electronic Journal for Leadership in Learning, 11(3). Retrieved from http://www.ucalgary.ca/iejll/vol11/huss

Lewin, K. (1941). Forces behind food habits and forces of change. In Committee on Food Habits, The National Academy of Sciences (Ed.), Problem of Changing Food Habits Report of the Committee on Food Habits 1941-1943. The National Academies Press. Washington, DC, USA.

Mason, R. W., \& Schroeder, M. P. (2010). Principal Hiring Practices: Toward a Reduction of Uncertainty. The Clearing House, 186-193. http://dx.doi.org/10.1080/00098650903583727

Mitchell, W. (2003). Bypass the gatekeeper to land an interview with the decision maker. Tech Republic. Retrieved from http://articles.techrepublic.com.com/5100-22-5034822.html

Peterson, K. D. (2002). Effective teacher hiring: A guide to getting the best. Alexandria, VA: Association of Supervision and Curriculum Development.

Phipps, R., \& Merisotis, J. (1999). What's the Difference? A review of contemporary research on the effectiveness of distance learning in higher education. Washington: The Institute for Higher Education Policy.

Russell, T. (1999). The 'no significant difference' phenomenon. Retrieved from http://nt.media.hku.hk/no_sig_diff/phenom1.html

Taylor, J. C. (2001). Fifth generation distance education. Retrieved from http://www.usq.edu.au/users/taylorj/conferences.htm

Topor, D. J., Colarelli, S. M., \& Han, K. (2007). Influences of traits and assessment methods on human resource practitioners' evaluations of job applicants. Journal of Business and Psychology, 21(3), 361-376. http://dx.doi.org/10.1007/s10869-006-9033-6

Trail, K. (October, 2000). Taking the lead: The role of a principal in school reform. CSRD Connections, 1(4), 1-4.

Zandberg, I., \& Lewis, L. (2008). Technology-Based Distance Education Courses for Public Elementary and Secondary School Students: 2002-03 and 2004-05 (NCES 2008-008). National Center for Education Statistics, Institute of Education Sciences, U.S. Department of Education. Washington, DC, USA. 


\section{Copyright Disclaimer}

Copyright for this article is retained by the author(s), with first publication rights granted to the journal.

This is an open-access article distributed under the terms and conditions of the Creative Commons Attribution license (http://creativecommons.org/licenses/by/3.0/). 